\title{
Impact of Leadership Style and Organizational Culture on Organizational Commitment
}

\author{
Naveeda K. Katper ${ }^{1}$, Naveed Iqbal Chaudhry ${ }^{2}$, Muhammad Nawaz Tunio ${ }^{3}$, \\ Muhammad Athar $\mathrm{Ali}^{2}$
}

\begin{abstract}
The purpose of this study is to explore the relationship between leadership style, organizational culture, and organizational commitment in Pakistani manufacturing companies. The data were collected through questionnaire distribution and online form filling by 520 middle and senior managers of the manufacturing companies through a simple random sampling technique.

The findings of the study are the transformational leadership style has a significant impact on organizational commitment, transactional leadership style has a low significant impact on organizational commitment. Bureaucratic organizational culture has the lowest impact, innovative organizational culture has the second-highest impact and supportive highest culture has the highest impact on organizational commitment. Organizational commitment depends upon the leadership style and organizational culture. Organizational culture should be supportive and innovative for the highest commitment of the employees. Low response rate and less participation by the female side are the limitations.

Although his study is conducted in Pakistan, it is expected that the results of our study may have relevance to the other countries. By reproducing this study in different contexts and countries our results would be very helpful to develop a new model of leadership and organizational culture with implementation techniques that can be easily operationalized in a cross-cultural context.
\end{abstract}

Keywords: Leadership style, organizational culture, organizational commitment, manufacturing companies, Pakistan

JEL Code: M31

\section{Introduction}

Organizational culture and leadership style got a lot of focus in the prior studies of the workplace (Mehmood, Jian, \& Gilal, 2020). Because these variables have general recognition and can be the major determinant of organizational effectiveness

${ }^{1}$ Institute of Business Administration, Faculty of Commerce and Business Administration, University of Sindh, Allama I.I. Qazi Campus Jamshoro, Pakistan.

${ }^{2}$ University of the Punjab Gujranwala Campus, Gujranwala, Pakistan

${ }^{3}$ Entrepreneurship, Innovation and Economic Development, Alpen Adria University, Klagenfurt, Austria

Corresponding author: m1tunio@edu.aau. 
(Laschinger, et al, 2001; Miller, 1978) and performance (Angle \& Perry, 1981; Riketta, 2002). A lot of literature has reported a strong relationship between organizational culture and organizational commitment (Benkhoff, 1997). For organizational commitment, the organizational culture plays an important role in developing commitment and increasing the performance of employees. Employees are less committed to their jobs when they are not satisfied/ happy with that job consequently, they start trying to search the new job and when finding no opportunity available outside in the market, they become mentally or emotionally fed up by the job and organizational environment (Rasid, et al, 2013; Zhang, et al., 2019). Therefore, organizational culture and organizational commitments are the vital stances to be committed and their contribution towards the organization.

Several experiences of organizational commitment have been recommended in past studies (Chen, 2004; Mathieu \& Zajac, 1990; Williams \& Hazer, 1986). For example, Lok \& Crawford (2004) stated that organizational culture (Trice \& Beyer, 1984) and leadership style (Williams \& Hazer, 1986) have a considerable impact on organizational commitment (Lok \& Crawford, 2004). Previous studies have already described that national culture can also influence the leadership style (Westwood \& Posner, 1997) and employees' behavior towards organizational commitment ( Miroshnik, 2002; Zhang et al., 2018). Literature suggests that leadership takes various forms, such as the Transformational Leadership Style over servant Leadership, Resonance, and others. Different types of leadership styles for example, transactional and transformational leadership styles having a significant impact on organizational commitment. According to researchers, transactional leadership plays multi roles as a manager because he is involved in physical and methodological procedures from the managerial aspects (Maduka and Okafor, 2014).

Thus the organizational commitment varies from culture to culture. Most recently, the research on the performance and motivation by using leadership style also suggests that it can help achievement in work if they can do their jobs well to achieve the specified work goals" (Wahyuni et al., 2020). In another study, researchers found that ethical leadership exerts a positive impact on psychological safety and feedback-seeking behavior (Gong, Liu, Xin, Gilal, Yin, \& Zhang, 2019). Therefore the authors conclude that ethical leadership is significant for psychological safety and feedback-seeking behavior in the context of high-power distance (Gong et al., 2019).

Moreover, the importance of leadership in the organizational commitment and performance of employees is unignorably rather has greater influence. because the leader is expected to be an inspirational character for subordinates in various ways such as achieving the company targets, improving company performance, improving motivation. That motivation may be creating harmony in working teams and can lead to achievements, affiliation, and respect. Good leadership is efficient in providing all kinds of required resources to the subordinate to perform well and achieve the goal of the firm. That increases the importance of leadership. Generally, in the literature

Sukkur IBA Journal of Management and Business - SIJMB | Vol 7 No. 1 January - June 2020 @ Sukkur IBA University 
leadership is defined as "the process of influencing people to accomplish organizational goals (McShane and Travaglione, 2003; Gilal, et al., 2020). However, other theorists opine it as the position, the process of influencing others, the responsibility, the accountability, a tool to accomplish a goal, the outcome of interaction, behaviors, and many more". Therefore, the meaning and role of leadership vary somehow for the different researchers (Limsila \& Ogunlana, 2008).

In this context, we investigate another aspect of this domain as this study aims to analyze the opinion of managerial level employees about their level of organizational commitment. The organizational variables like leadership style and organizational culture were chosen as the determinant for our present research work. This study will also check the influence of demographic factors like gender, age, education level, and tenure in the organization. The study is further structured as follows; the literature review is discussed in section 2, methodology in section 3. Section four provides an analytical discussion of the study. In section five research implications are discussed and section 6 gives research limitations and future recommendations of the study. Section seven is dedicated to the conclusion of the research.

\section{Literature review}

Plenty of research is available in the literature regarding leadership from a different perspective such as on styles of leaders, organizational environment, and employees' commitment. Many versions of leadership affect employee commitment, for example, the past studies focused on transactional leadership, transformational leadership, empowering leadership, among others (Anseel et al., 2015), ethical leadership and feedback-seeking (Brown et al. 2005). In this context, recently Gong et al., (2019) attempted to check a "mediating role of psychological safety in the relationship between ethical leadership and nurse's feedback seeking", and moderating effect of power distance. Their findings show that ethical leadership positively affects employees' feedback-seeking by psychological safety. Batra and Hyde, (2020), highlighted the "constructs of leadership, commitment, and socialization in the construction sector by investigating the relationship between the constructs". Hence it is concluded that "the leadership style, which is relevant for construction professionals, is authentic leadership, and authentic leadership has the potential to moderate the relationship between socialization domains and affective commitment". In this way, many other researchers also study in various ways to explore the domain of leadership and cultural or organizational commitments in different ways, for example, some studies in the literature are given below in this regard.

\subsection{National culture and Organizational Commitment}

There may be a difference in employee's commitment, performance, behavior, and expectations in different national cultures of different countries. National culture also plays an important role to tell how the organizations are managed and what is the hierarchy of the organizations (Lok \& Crawford, 2004). The demographic factors like age, tenure, education, gender are also having an impact on organizational commitment 
(MChen, 2004; Gong, et al., 2020). As far as the national culture is concerned in the eastern areas the companies are normally family owned and have bureaucratic styles, centralized decision making while in western countries, the companies are normally owned by public shareholders, they have managers as their representatives in the company and have decentralized decision making, less bureaucratic structure and they promote the individualism (Chen, 2004; El-Kahal, 2001; Mehmooda, et al., 2020).

\subsection{Leadership style and organizational culture}

"A leader is defined as the person who influences a group to attain the group's goals" (Chen, Chen, \& Chen, 2010). While the "Organizational culture is a pattern of shared basic assumptions that the group learned as it solved its problems of external adaptation and internal integration, that has worked well enough to be considered valid and, therefore, to be taught to new members as the correct way you perceive, think and feel concerning those problems" (Khan \& Rashid, 2012; Gilal, et al., 2019). A major portion of organizational culture is developed by the leaders while on the other side organizational culture may affect the improvement of its leaders. Employees can work hard, by innovations and creativity when they were administered by a supportive culture or manner (Tierney, Farmer, \& Graen, 1999; Chen, Zhang, \& Gilal, 2019).

\subsection{Leadership style and organizational commitment}

"Organizational commitment is work attitude that is directly related to employee participation and intention to remain with the organization and is linked to job performance" (Mathieu \& Zajac, 1990). The work of a leader is not to just supervise or command his followers but it is the responsibility of the leaders to make their subordinates able to achieve their goals. Although the leaders need to control, support the employees' thinking, plan suggestions and proposals to assist and influence them, that would motivate the employees to explore their ideas for innovations and decision making (Rhoades \& Eisenberger, 2002; Gilal, et al., 2019). When a supportive leader is there then employees and subordinates show loyalty for the job and less number of absentees will occur, it creates trust in the leaders. Ultimately the efficiency and the effectiveness of the organization will be enhanced. Leadership plays an important role in the victory or collapse of the organization. Burns (1978) describes that mutual thoughtfulness of leaders and followers for managing and controlling organizational functions may increase the loyalty and moral values towards the organization and employees, employees then prefer the organizational goals rather than their selforiented goals (Bass, 1985). Burns (1978) stated that "transformational leadership is observed when leaders encouraged followers to boost up the level of their morals, motivation, beliefs, perceptions, and coalition with the objectives of the organization."'(Avolio, Zhu, Koh, \& Bhatia, 2004; Neese-Smith, 1997) researched staff nurses of a public hospital and stated that the transformational leadership style has a positive impact on organizational commitment. Transactional leadership motivate employees or their subordinates for organizational commitment and to increase their

Sukkur IBA Journal of Management and Business - SIJMB | Vol 7 No. 1 January - June 2020 @ Sukkur IBA University 
performance (Martinsuo, Hensman, Artto, Kujala, \& Jaafari, 2006; Riggio \& Reichard, 2008; Sivanathan \& Fekken, 2002).

H1: Leadership style has a significant positive impact on organizational commitment.

\subsection{Organizational culture and organizational commitment}

Organizational commitment is defined as "multidimensional in nature. It reflects the degree of goal and value congruency with the organization, employees' loyalty to the organization, willingness to exert effort on behalf of the organization, and maintain the membership in the organization"(Bateman \& Strasser, 1984). In organizational culture, three types of cultures are discussed. "Bureaucratic cultures have clear lines of responsibility and authority; work is highly organized, compartmentalized, and systematic. The information and authority flow is hierarchical and based on control and power" (Koberg \& Chusmir, 1987; Wallach, 1983). Most researchers agree that strong bureaucratic culture is a source of attraction and retaining the employees who are not creative and nor risk-takers (Kaplan, 1983; M. Kirton, 1976; Kirton, 1984). In innovative cultures, "These are creative work environments where challenge and risktaking are the norms. Stimulation is a constant companion to workers in this culture, but innovative environments also take their toll on people who often are under great stress and burned out"(Koberg \& Chusmir, 1987). Due to this culture, the employees seem to be more participative and committed to their goals. Supportive cultures are defined as "The work environment is friendly, and workers tend to be fair and helpful to each other and to the organization. An open, harmonious environment is encouraged and 'family' values are promoted" (Koberg \& Chusmir, 1987). Bureaucratic work environment causes negative employee commitment while the supportive organizational culture causes positive employee commitment and greater work involvement (Brewer, 1993; Odom, Boxx, \& Dunn, 1990). When employees support each other on the job, everybody tends to be motivated and ultimately they are more committed to the jobs and perform well. Zeffane(1995) researched in Australia on the employees of the public and private sector and concluded that employees in private sector organizations are more committed to their jobs than the public sector. The main focus on organizational commitment shows that organizational commitment is the central part of the organization which represents the positive attitudes of the employees and the desired output of the employees towards the organizational commitment (Bartlett, 2001). Lok \& Crawford (2004) studied the 337 managers from Hongkong and Australia, as a result, they describe that Australian managers are more committed to their jobs than Hongkong managers because of cultural differences. According to Lee \& Olshfski (2002) when employees get the jobs, they analyze the status and rank attached to it, accordingly they are committed to the job and give output as per requirements of the organization.

H2: Innovative and supportive organizational culture has a positive impact on organizational commitment.

Sukkur IBA Journal of Management and Business - SIJMB | Vol 7 No. 1 January - June 2020 @ Sukkur IBA University 
Proposed Model:

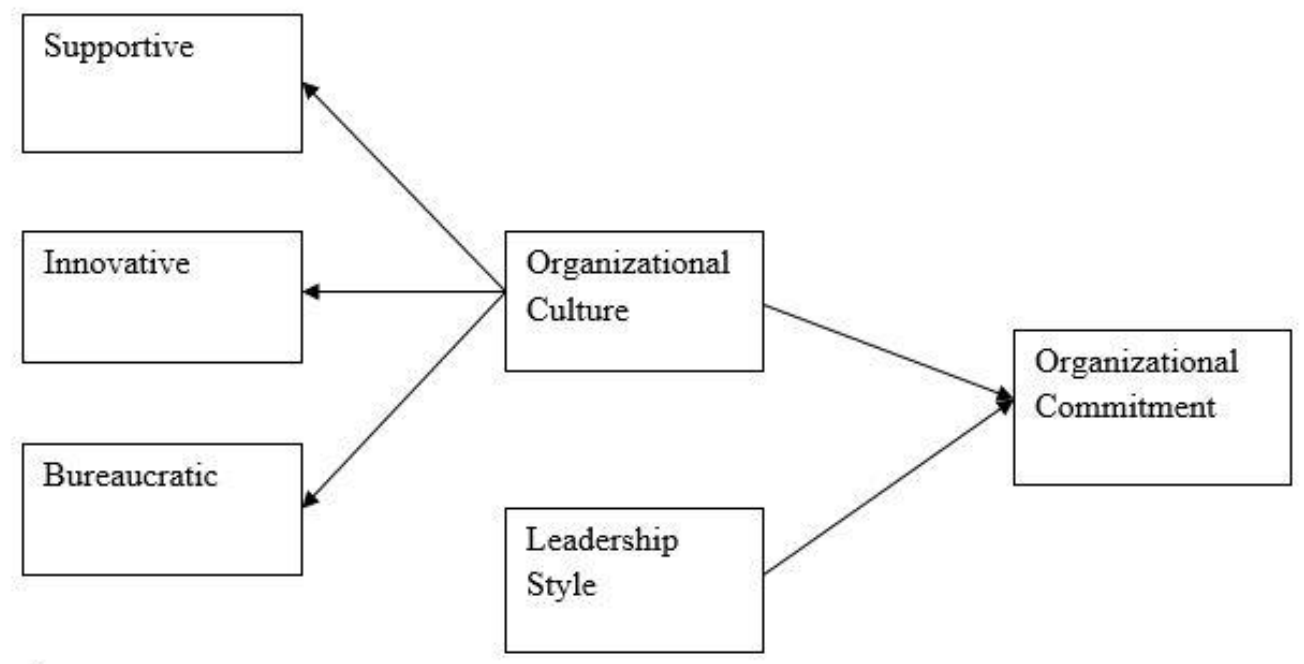

\section{Methodology}

We conduct the quantitative research to test the relationships between the constructs of the model included in this study so the nature of our study is empirical. A cross-sectional study has been implied in this research with a non-contrived study setting. Our target population is the middle and senior managers having bachelor's and master's degrees in manufacturing companies. The sampling technique which we used in this research is Non-Probability simple random sampling because we select the companies randomly from Gujranwala and Sialkot Region. According to Kline (2011), we select the sample size for data collection as 520 which is a multiple of 10 of the items included in the questionnaire. The data was collected from those middle and senior managers who had bachelor and master degrees in the field of business administration. The questionnaires were given to the respective respondents providing the time of one week. We distributed 520 questionnaires from which 350 questionnaires were returned and 197 questionnaires were found capable of data analysis. Therefore, we implemented the primary type of data collection method.

\subsection{Measures}

For data collection, the questionnaire has four sections. Section 1 st was related to the Wallach (1983) organizational cultural index (OCI) that explains organizational culture in three ways according to three different and distinct dimensions which are bureaucratic, supportive, and innovative. Koberg \& Chusmir (1987) has also used the OCI. In the questionnaire, this section has 24 items and used the Likert scale as ranging from one (does not describe the organization most of the time) to five (describe the organization most of the time). Section 2 is related to the Bass \& Avolio (1990) 
leadership behavior questionnaire (LBQ). It has 13 items that are assigned to the transformational and transactional leadership styles. It was a very well established questionnaire and has been extensively used in past researches.

Section 3 is related to Mowday, Steers, \& Porter, (1979) organizational commitment questionnaire (OCQ). It has been frequently used by past researchers. The Mowday et al's(1979) (OCQ) contains 15 items. For each item, a statement is there (For example, "I am proud to tell others that I am part of this organization".) and survey participants respond to those questions using 5 points Likert scale, ranging from strongly disagree (1) to Strongly Agree (5).

\subsection{Data analysis}

For data analysis, we apply a structured equation modeling technique (SEM). Because this is the latest technique and more than one analysis can be run simultaneously. We used the Statistical package for social sciences (SPSS) version 21, and AMOS version 22 computer operated software for data analysis.

\section{Results and analysis}

For applying CFA and SEM the normality and reliability of the data must be ensured. The mean of all variables is from 4.1961 to 4.4289 and their standard deviation from 0.723 to 0.896 therefore, there is no normality issue. The reliability of the data can be checked using Cronbach's alpha. It must be greater than 0.7 according to Cronbach's Alpha (1951). The values of $\alpha$ of all the variables are acceptable and make the data reliable. The mean Cronbach's Alpha and standard deviation values of all the variables are shown in Table 1.

Table 1: Descriptive Statistics

\begin{tabular}{|l|c|c|c|}
\hline \multicolumn{1}{|c|}{ Variables } & Mean & $\begin{array}{c}\text { Standard } \\
\text { Deviation }\end{array}$ & $\begin{array}{c}\text { Cronbach's } \\
\text { Alpha }\end{array}$ \\
\hline Organizational Commitment & 4.2116 & .79370 & .972 \\
\hline Transformational Leadership style & 4.1997 & .80578 & .962 \\
\hline Transactional Leadership style & 4.4289 & .72318 & .832 \\
\hline $\begin{array}{l}\text { Supportive Organizational culture } \\
\text { (SOC) }\end{array}$ & 4.1961 & .89608 & .962 \\
\hline $\begin{array}{l}\text { Innovative Organizational culture } \\
\text { (IOC) }\end{array}$ & 4.3090 & .76271 & .949 \\
\hline $\begin{array}{l}\text { Bureaucratic Organizational } \\
\text { culture(BOC) }\end{array}$ & 4.2377 & .79684 & .922 \\
\hline
\end{tabular}

Gerbing \& Anderson (1988) give the two-step approach. According to them, confirmatory factor analysis (CFA) has to be performed first. The second step which we perform to test our postulated hypothesis will be the SEM. Now, at first, we draw out all the variables with their relative constructs to perform the CFA in AMOS. After

Sukkur IBA Journal of Management and Business - SIJMB | Vol 7 No. 1 January - June 2020 @ Sukkur IBA University 
that, we draw covariance between all variables to covariate with each other. In this study, each item is loading in its corresponding construct that is verification for the successful execution of the CFA. That is shown in Table 2. Then we calculate the results. Before checking the convergent and discriminant validity, we ensure model fit indices that data has recognized as a fit model. According to Kline \& hair the model fit indices are, as chi-square should be less than 3, CFI should be $>.95$, GFI should be $>.95$, AGFI should be >.80, RMR should be <.09, RMSEA should be <.05, and PCLOSE should be $>.05$.

According to results, Chi-square of our data is 1.572 , CFI is .938 , AGFI is .733 which is moderate, RMR is .040, and RMSEA is .054. Thus all the values of model fit indices are in an acceptable range. Therefore, we can say that our model is successfully fit. During the execution of CFA, according to Gerbing \& Anderson, (1988), we have to clear that there should be no validity and reliability issue in the data. To check the validity of the data we follow Kline 2011 . Here validity means the convergent validity and discriminant validity. Furthermore, in the process of performing the CFA to analyze the Convergent and Discriminant validity, we follow the Fornell \& Larcker, (1981)s' three-step approach. Fornell \& Larcker, (1981) argue that for Convergent validity, the composite reliability of all the variables should be greater than 0.8 , factor loading of all the constructs should be higher than 0.7, and average variance extracted (AVE) should be greater than 0.5 . If all the values lie in this range, then it means that there is no convergent validity issue.

For analyzing the discriminant validity of the data we take the square root of AVE which should be greater than the correlational values of all the variables. If the resulting values meet the criteria, it would be understood that there is no discriminant validity issue. When discriminant validity and convergent validity would be out of issues and complete requirements then CFA has been successfully executed. The Composite reliability and AVE of all the variables are presented in Table 3. Here in Table 2, the factor loading of all the variables is higher than 0.7 , which means there is no issue of convergent validity.

Table 2 Factors Loading

\begin{tabular}{|c|c|c|}
\hline Variables & $\begin{array}{l}\text { No of } \\
\text { Items }\end{array}$ & Factor Loadings \\
\hline Organizational Commitment (OC) & 13 & $\begin{array}{l}.856, .848, .852, .882, .847, \\
.847, .864, .852, .859, .838, \\
.844, .855, .847\end{array}$ \\
\hline Organizational Commitment (OC) & 9 & $\begin{array}{l}.932, .874, .847, .883, .839, \\
.856, .850, .822, .845\end{array}$ \\
\hline Transformational Leadership style & 2 & $.729, .978$ \\
\hline $\begin{array}{l}\text { Supportive Organizational culture } \\
\text { (SOC) }\end{array}$ & 8 & $\begin{array}{l}.866, .893, .861, .865, .870, \\
.873, .863, .883\end{array}$ \\
\hline $\begin{array}{l}\text { Innovative Organizational culture } \\
\text { (IOS) }\end{array}$ & 8 & $\begin{array}{l}.861, .862, .846, .836, .825, \\
.824, .820,825\end{array}$ \\
\hline
\end{tabular}

Sukkur IBA Journal of Management and Business - SIJMB | Vol 7 No. 1 January - June 2020 ๑ Sukkur IBA University 


\begin{tabular}{|l|l|l|}
\hline \hline $\begin{array}{l}\text { Bureaucratic Organizational culture } \\
\text { (BOS) }\end{array}$ & 6 & $\begin{array}{l}.866, .823, .841, .849, .850, \\
.862\end{array}$ \\
\hline
\end{tabular}

Table 3: Psychometric properties

\begin{tabular}{|l|c|c|c|c|c|c|c|c|}
\hline Constructs & CR & AVE & B_OC & OC & Trf_LS & S_OC & I_OC & Trs_LS \\
\hline B_OC & 0.923 & 0.667 & 0.817 & & & & & \\
\hline OC & 0.972 & 0.728 & $0.237^{* *}$ & 0.853 & & & & \\
\hline Trf_LS & 0.962 & 0.740 & $0.245^{* *}$ & $0.483^{* *}$ & 0.860 & & & \\
\hline S_OC & 0.962 & 0.760 & $0.467^{* *}$ & $0.384^{* *}$ & $0.371^{* *}$ & 0.872 & & \\
\hline I_OC & 0.949 & 0.701 & $0.173^{* *}$ & $0.177^{* *}$ & $0.152^{* *}$ & $0.199^{* *}$ & 0.838 & \\
\hline Trs_LS & 0.851 & 0.744 & $0.199^{* *}$ & $0.343^{* *}$ & $0.307^{* *}$ & $0.396^{* *}$ & $0.009^{* *}$ & 0.863 \\
\hline
\end{tabular}

$\mathrm{BOC}=$ Bureaucratic Organizational culture $(\mathrm{BOC})$

$\mathrm{OC}=$ Organizational Commitment (OC)

Trf- LS= Transformational Leadership style

$\mathrm{SOC}=$ Supportive Organizational culture (SOC)

IOC= Innovative Organizational culture (IOC)

Trs-LS= Transactional Leadership style

The composite reliability of all the variables of our data is greater than 0.8 and the average variance extracted is also greater than 0.5 which also is a sign that there is no convergent validity issue, as shown in table 3 . For discriminant validity, the square root of AVE is also greater than the correlational values of all the variables which depict that our discriminant validity is also acceptable. After confirming that there is no convergent and discriminant validity issue in our data and CFA has been successfully tested, we can run SEM for hypothesis testing. For testing the hypothesis, we converted our model into a structural model by drawing the paths for our proposed relationships. For structured equation modeling (SEM) our model fit indices are as Chi-square is 1.572, AGFI is .733 which is moderate, RMR is .040, CFI is .938, RMSEA is .054 all the values are in the acceptable range. Now we check the proposed relationship of our study through SEM.

First, we check the H1, in which we postulated that transactional and transformational leadership styles have a significant impact on organizational commitment, transformational leadership style (Standardized $\beta=.354, \mathrm{p}=0.00$ ) and for transactional leadership style (Standardized $\beta=.166, p=.019$ ) which shows that our results are supporting $\mathrm{H} 1$. The $\mathrm{H} 2$ of this research is the supportive and innovative organizational culture significantly influences organizational commitment. There is strong relationship between supportive organizational culture (SOC) and organizational commitment (Standardized $\beta=.156, \mathrm{p}=.051$ ), but some weak relationship between innovative organizational culture (IOS) and organizational commitment (Standardized $\beta=.085, \mathrm{p}$ $=.188$ ). Our results show that there is a strong and negative relationship between 
bureaucratic organizational culture and organizational commitment (Standardized $\beta=$ $.029, \mathrm{p}=.688$ ). Similar to the study of Silverthorne, (2004), conducted in the USA, California, bureaucratic organizational culture have the lowest impact on organizational commitment, Innovative organizational culture has the next highest level of organizational commitment and supportive organizational culture has the highest level of organizational commitment. Our results are consistent with the results of (Silverthorne, 2004). In our study, Hypothesis 2 has three dimensions out of which two are accepted and one is rejected as bureaucratic culture has the lowest impact on organizational commitment.

Table 4: Regression weights

\begin{tabular}{|l|c|c|c|c|c|}
\hline \multicolumn{1}{|c|}{ Relationships } & US $\beta$ & S $\beta$ & S.E. & C.R. & P \\
\hline Trf_LS $\rightarrow$ OC & .307 & .354 & .062 & 4.987 & $* * *$ \\
\hline Trs_LS $\rightarrow$ OC & .226 & .166 & .097 & 2.342 & .019 \\
\hline S_OC $\rightarrow$ OC & .139 & .156 & .071 & 1.949 & .051 \\
\hline I_OC $\rightarrow$ OC & .084 & .085 & .064 & 1.315 & .188 \\
\hline B_OC $\rightarrow$ OC & .027 & .029 & .066 & .402 & .688 \\
\hline Note: ns=not-significant, $\uparrow=\mathrm{p}, 0.1 *=\mathrm{p}<.05, * *=\mathrm{p}<0.01, * * *=\mathrm{p}<.001$ \\
\hline
\end{tabular}

Trs-LS $=$ Transactional Leadership style

$\mathrm{BOC}=$ Bureaucratic Organizational culture $(\mathrm{BOC})$

$\mathrm{OC}=$ Organizational Commitment $(\mathrm{OC})$

Trf- LS = Transformational Leadership style

SOC $=$ Supportive Organizational culture (SOC)

IOC= Innovative Organizational culture (IOC)

\section{Research Implications}

Research implications for theory: The theoretical background of this study is in the context of "leadership styles, organizational culture, and organizational commitment", for the sample containing three cities mentioned in the above sections. Therefore, this paper aims to verify that organizational culture and leadership style are significant elements of organizational commitment. The purpose is to ensure the relationship between leadership styles and the performing employees' commitment. By conducting this study, we examine and check the effect of variables [(Organizational Commitment, Transformational Leadership style, Transactional Leadership style, Supportive Organizational culture (SOC), Innovative Organizational culture (IOC), Bureaucratic Organizational culture(BOC)] to extend in the literature with organizational culture and leadership by unique sample regarding different cities. The findings support that the organizational culture should be supportive and innovative for the highest commitment of the employees because the organizational commitment depends upon the leadership styles and organizational culture. 
Research Implications for practice: The implications of this study for managers are important. Although his study is conducted in Pakistan, it is expected that the findings of our study may have relevance to the other countries too. By reproducing this research in different contexts and countries, this study would be very helpful to develop a new model of leadership and organizational culture with implementation techniques that can be easily operationalized in a cross-cultural context. This study will help out the organizations to establish their organizational cultures and leadership styles for committing their employees to the organization. As much as the employees are committed to their organizations the organizational performance can be enhanced. Employees can work hard and bring innovations and creativity when they were administered by a supportive culture.

\section{Limitations and Future Recommendations}

One of the limitations of this study is the nature of the sample. That is a low response rate and less participation by the female side, thus mostly the data has been collected from the male side. Furthermore, the other limitation is that the samples for data collection have been taken from three cities Gujranwala, Gujarat, and Sialkot; the data couldn't be taken from other cities. Finally, people of the organizations (respondents) are unable to respond, even they are in management positions but they didn't understand the research work and keep away themselves in giving the response. Therefore, our response rate is very low.

We suggest that for next time females and other cities of Pakistan should be explored for the sample. Moreover, according to the authors, the future researcher should be included some interesting topics for checking the cross-cultural responses. Hence, we recommend that in this model for "Organizational Performance" the other variables like cross-cultural responses for testing should be included because organizational commitment can have a positive impact on organizational performance.

\section{Conclusion}

To conclude, this research is a dynamic effort to analyze the impact of leadership style and organizational culture on organizational commitment. The study analyses the responses and the approach of employees at a managerial level about organizational commitment. In this regard, different variables such as leadership style and organizational culture are used as a determinant of this research work. This study also checks the influence of demographic factors like gender, age, education level, and tenure in the organization. Hypothesis one is proved which postulated that Transactional and Transformational leadership styles have a significant impact on Organizational commitment. Our results also support the hypothesis two that is the Supportive and innovative organizational culture significantly impacts on Organizational Commitment. Therefore, results show the strong relationship between supportive organizational culture (SOC) and organizational commitment. this research reveals that there is a strong negative relationship between Bureaucratic organizational culture and organizational commitment consistent with the results of (Silverthorne, 
2004). In this study, hypothesis 2 has three dimensions out of which two are accepted and one is rejected as Bureaucratic culture has the lowest impact on organizational commitment. Even though some results of this research are left unsolved, it has suggested some interesting topics to investigate these variables. This research verifies that organizational culture and leadership style are significant antecedents of organizational commitment. This study will help out the organizations to take some steps regarding their organizational cultures and leadership styles for committing their employees to the organization. As much as the employees are committed to their organizations the organizational performance can be enhanced.

\section{References:}

Angle, H. L., \& Perry, J. L. (1981). An empirical assessment of organizational commitment and organizational effectiveness. Administrative Science Quarterly, 26(1).

Anseel, F., Beatty, A. S., Shen, W., Lievens, F., and Sackett, P. R. (2015). How are we doing after 30 years? A meta-analytic review of the antecedents and outcomes of feedbackseeking behavior. J. Manag. 41, 318-348. doi: 10.1177/0149206313484521

Avolio, B. J., Zhu, W., Koh, W., \& Bhatia, P. (2004). Transformational leadership and organizational commitment: Mediating role of psychological empowerment and moderating role of structural distance. Journal of Organizational Behavior, 25(8), 951968.

Bartlett, K. R. (2001). The relationship between training and organizational commitment: A study in the health care field. Human Resource Development Quarterly, 12(4), 335-352.

BATRA, S. \& HYDE, A. M. 2020. Leadership, Commitment, and Socialization in the Construction Sector-A Concise Exploration. International Management Review, 16.

Bass, B. M. (1985). Leadership and performance beyond expectations. Collier Macmillan. Retrieved from http://agris.fao.org/agrissearch/search/display.do?f=2013/US/US2013043070004307.xml;US201300430719

Bass, B. M., \& Avolio, B. J. (1990). Transformational leadership development: Manual for the multifactor leadership questionnaire. Consulting Psychologists Press Palo Alto, CA.

Bateman, T. S., \& Strasser, S. (1984). A longitudinal analysis of the antecedents of organizational commitment. Academy of Management Journal, 27(1), 95-112.

Benkhoff, B. (1997). Disentangling organizational commitment: The dangers of the OCQ for research and policy. Personnel Review, 26(1/2), 114-131.

Brown, M. E., Treviño, L. K., and Harrison, D. A. (2005). Ethical leadership: a social learning perspective for construct development and testing. Organ. Behav. Hum. Dec. 97, 117134. doi: 10.1016/j.obhdp.2005.03.002

Brewer, A. M. (1993). Managing for employee commitment. Longman Professional.

Burns, J. M. (1978). Leadership in New York. NY: Harper and Row Publishers.

Chen, L.-T., Chen, C.-W., \& Chen, C.-Y. (2010). Are educational background and gender moderator variables for leadership, satisfaction and organizational commitment. African Journal of Business Management, 4(2), 248-261.

Chen, C. X., Zhang, J., \& Gilal, F. G. (2019). Composition of motivation profiles at work using latent analysis: theory and evidence. Psychology Research and Behavior Management, 12, 811-824.

Chen, M. (2004). Asian management systems: Chinese, Japanese and Korean styles of business. Cengage Learning EMEA.

Sukkur IBA Journal of Management and Business - SIJMB | Vol 7 No. 1 January - June 2020 (C) Sukkur IBA University 
Chen, Z. X., \& Francesco, A. M. (2000). Employee demography, organizational commitment, and turnover intentions in China: do cultural differences matter? Human Relations, 53(6), 869-887.

El-Kahal, S. (2001). Business in the Asia Pacific. OUP Catalogue. Retrieved from http://ideas.repec.org/b/oxp/obooks/9780198782193.html

Fornell, C., \& Larcker, D. F. (1981). Evaluating structural equation models with unobservable variables and measurement error. Journal of Marketing Research, 39-50.

Gerbing, D. W., \& Anderson, J. C. (1988). An updated paradigm for scale development incorporating unidimensionality and its assessment. Journal of Marketing Research, 186192.

Gilal, F. G., Gilal, N. G., Channa, N. A., Gilal, R. G., Gilal, R. G. and Tunio, M. N. (2020). Towards an integrated model for the transference of environmental responsibility. Business Strategy abd Environment 1-10.

Gilal, F. G., Channa, N. A. Gilal, N. G. Gilal, R. G. Shah, S. M. M. (2019). Association between a teacher's work passion and a student's work passion: a moderated mediation model. Psychology Research and Behavior Management 12, 889-900.

Gilal, F. G., Ashraf, Z, Gilal, N. G., Gilal, R. G. and Channa, N. A. (2019). Promoting environmental performance through green human resource management practices in higher education institutions: A moderated mediation model. Corp Soc Resp Env Ma. 26, 1579-1590. DOI: 10.1002/csr.1835

Gong, Z., Van Swol, L., Xu, Z., Yin, K., Zhang, N., Gilal, F. G. \& LI, X. (2019). High- power distance is not always bad: ethical leadership results in feedback Seeking. Frontiers in psychology, 10.

Gong, Z., Yang, j., Gilal, G. G., Van Swol, L. M. andYin, K. (2020). Repairing Police Psychological Safety: The Role of Career Adaptability, Feedback Environment, and Goal-Self Concordance Based on the Conservation of Resources Theory. SAGE Open 111. DOI: $10.1177 / 2158244020919510$

Gong, Z., Liu, M., Xin, D., Gilal, F. G., Yin, K., \& Zhang, N. (2019). Coworker feedback seeking and feedback environment in China: An expectation states theory approach. Social Behavior and Personality: an international journal, 47(9), 1-10.

Kaplan, R. E. (1983). The perils of intensive management training and how to avoid them. Professional Psychology: Research and Practice, 14(6), 756.

Khan, S. J. K., \& Rashid, M. Z. A. (2012). The mediating effect of organizational commitment in the organizational culture, leadership and organizational justice relationship with organizational citizenship behaviour: A study of academicians in private higher learning institution in Malaysia. International Journal of Business and Social Sciences, 3(8), 8391.

Kirton, M. (1976). Adaptors and innovators: A description and measure. Journal of Applied Psychology, 61(5), 622.

Kirton, M. J. (1984). Adaptors and innovators-Why new initiatives get blocked. Long Range Planning, 17(2), 137-143.

Koberg, C. S., \& Chusmir, L. H. (1987). Organizational culture relationships with creativity and other job-related variables. Journal of Business Research, 15(5), 397-409.

Laschinger, H. K. S., Finegan, J., \& Shamian, J. (2001). The impact of workplace empowerment, organizational trust on staff nurses' work satisfaction and organizational commitment. Health Care Management Review, 26(3), 7-23.

Sukkur IBA Journal of Management and Business - SIJMB | Vol 7 No. 1 January - June 2020 @ Sukkur IBA University 
Lee, S.-H., \& Olshfski, D. (2002). Employee commitment and firefighters: It's my job. Public Administration Review, 62(s1), 108-114.

Limsila, K. \& Ogunlana, S. O. 2008. Performance and leadership outcome correlates of leadership styles and subordinate commitment. Engineering, construction and architectural management.

Lok, P., \& Crawford, J. (2004). The effect of organisational culture and leadership style on job satisfaction and organisational commitment: A cross-national comparison. Journal of Management Development, 23(4), 321-338. http://doi.org/10.1108/02621710410529785

Maduka, C. E. \& Okafor, O. 2014. Effect of motivation on employee productivity: A study of manufacturing companies in Nnewi. International Journal of Managerial Studies and Research, 2, 137-147.

Martinsuo, M., Hensman, N., Artto, K., Kujala, J., \& Jaafari, A. (2006). Project-based management as an organizational innovation: Drivers, changes, and benefits of adopting project-based management. Project Management Journal, 37(3), 87.

Mathieu, J. E., \& Zajac, D. M. (1990). A review and meta-analysis of the antecedents, correlates, and consequences of organizational commitment. Psychological Bulletin, 108(2), 171.

Mehmood, M. S., Jian, Z., \& Gilal, F. G. (2020). Entrepreneurial leadership and employee innovative behavior: Intervening role of creative self-efficacy. Human Systems Management, (Preprint), 1-13.

McNeese-Smith, D. K. (1997). The influence of manager behavior on nurses' job satisfaction, productivity, and commitment. Journal of Nursing Administration, 27(9), 47-55.

Miller, D. B. (1978). Career planning and management in organizations. SAM Advanced Management Journal, 43(2), 33-43.

Mehmooda, M. S., Jiana, Y. and Gilalb, F. G. (2020). Entrepreneurial leadership and employee innovative behavior: Intervening role of creative self-efficacy. Human Systems Management xx (20xx) x-xx DOI 10.3233/HSM-190783 IOS Press.

Miroshnik, V. (2002). Culture and international management: a review. Journal of Management Development, 21(7), 521-544.

Mowday, R. T., Steers, R. M., \& Porter, L. W. (1979). The measurement of organizational commitment. Journal of Vocational Behavior, 14(2), 224-247.

Odom, R. Y., Boxx, W. R., \& Dunn, M. G. (1990). Organizational cultures, commitment, satisfaction, and cohesion. Public Productivity \&amp; Management Review, 157-169.

Rasid, S. Z. A., Manaf, M. A. A., \& Quoquab, F. (2013). Leadership and Organizational Commitment in the Islamic Banking Context: The Role of Organizational Culture as a Mediator. American Journal of Economics, 3(5C), 171-176.

Rhoades, L., \& Eisenberger, R. (2002). Perceived organizational support: a review of the literature. Journal of Applied Psychology, 87(4), 698.

Riggio, R. E., \& Reichard, R. J. (2008). The emotional and social intelligences of effective leadership: An emotional and social skill approach. Journal of Managerial Psychology, 23(2), 169-185.

Riketta, M. (2002). Attitudinal organizational commitment and job performance: a metaanalysis. Journal of Organizational Behavior, 23(3), 257-266.

Salancik, G. R. (1977). Commitment and the control of organizational behavior and belief. New Directions in Organizational Behavior, 1-54.

Silverthorne, C. (2004). The impact of organizational culture and person-organization fit on organizational commitment and job satisfaction in Taiwan. Leadership \& Organization Development Journal, 25(7), 592-599. 
Sivanathan, N., \& Fekken, G. C. (2002). Emotional intelligence, moral reasoning and transformational leadership. Leadership \& Organization Development Journal, 23(4), 198-204.

Sommer, S. M., Bae, S.-H., \& Luthans, F. (1996). Organizational commitment across cultures: The impact of antecedents on Korean employees. Human Relations, 49(7), 977-993.

Tierney, P., Farmer, S. M., \& Graen, G. B. (1999). An examination of leadership and employee creativity: The relevance of traits and relationships. Personnel Psychology, 52(3), 591620.

Trice, H. M., \& Beyer, J. M. (1984). Studying organizational cultures through rites and ceremonials. Academy of Management Review, 9(4), 653-669.

Wallach, E. J. (1983). Individuals and organizations: The cultural match. Training \& Development Journal. Retrieved from http://psycnet.apa.org/psycinfo/1983-22213-001

Westwood, R. I., \& Posner, B. Z. (1997). Managerial values across cultures: Australia, Hong Kong and the United States. Asia Pacific Journal of Management, 14(1), 31-66.

Wahyuni, N. P. D., Purwandari, D. A. \& Syah, T. Y. R. (2020). Transactional Leadership, Motivation and Employee Performance. Journal of Multidisciplinary Academic, 3, 156161.

Williams, L. J., \& Hazer, J. T. (1986). Antecedents and consequences of satisfaction and commitment in turnover models: A reanalysis using latent variable structural equation methods. Journal of Applied Psychology, 71(2), 219.

Zeffane, R. (1995). Organizational commitment and perceived management styles: The publicprivate sector contrast. Management Research News, 18(6/7), 9-20.

Zhang, N., Gong, Z. X., Xu, Z., \& Gilal, F. G. (2019). Ethical climate and service behaviours in nurses: The moderating role of employment type. Journal of Advanced Nursing, 75(9), 1868-1876.

Zhang, N., Li, J., Bu, X., Gong, Z., \& Gilal, F. G. (2018). Bridging the Gap between Ethical Climate and Nurses' Service Behaviors: The Critical Role of Professional Wellbeing. International Journal of Mental Health Promotion, 20(3), 99-110. 